Doi: HTTPS://DOI.ORG/10.23910/IJBSM/2017.8.6.1832d

\title{
Influence of dates of Sowing on Quality and Yield Potential in Rabi Sorghum Genotypes
}

\author{
Chaithra V. ${ }^{*}$, D. S. Uppar ${ }^{3}$ and Kiran B. $0 .{ }^{2}$
}

${ }^{1}$ Dept. of Seed Science and Technology, ${ }^{3}$ University of Agricultural Sciences, Dharwad, Karnataka (580 005), India

${ }^{2}$ AICRP, Sorghum Improvement, RARS, Vijayapur, Karnataka (586 101), India

\section{Corresponding Author}

Chaithra V.

e-mail: chaithra1523@gmail.com

\author{
Article History \\ Article ID: AR1832d \\ Received in $10^{\text {th }}$ August, 2017 \\ Received in revised form $19^{\text {th }}$ November, 2017 \\ Accepted in final form $25^{\text {th }}$ November, 2017
}

\begin{abstract}
Sorghum is predominantly grown under rainfed conditions, subjected to many biotic and abiotic stresses which are influenced by weather. Weather aberrations during crop growth and development results in drastic reduction in yield and quality. The time of sowing is one important decisive factor that has direct bearing on weather conditions, the crop encounter. Hence, the field experiment was conducted to evaluate the sorghum genotypes for cold tolerance under varied dates of sowing. The quality parameters such as seed germination, seedling shoot and root length, seedling dry weight and vigour index differed significantly with dates and genotypes. Standard germination (92.60 $\%)$, root length $(15.22 \mathrm{~cm})$, seedling vigour index $(3,372)$ and seedling dry weight $(15.94 \mathrm{mg})$ were observed significantly higher under the September $30^{\text {th }}$ sowing compared to other dates of sowing. Among the genotypes significantly higher seed yield was recorded in genotype BJV-44 (1317 kg ha-1) and 39th standard week recorded maximum seed yield (1378 kg ha-1) followed by $41^{\text {st }}\left(1212 \mathrm{~kg} \mathrm{ha}^{-1}\right)$. The influence of temperature had a greater impact on seed yield in genotype BJV- 44 i.e when lower temperature $\left(29.60^{\circ} \mathrm{C}\right)$ coincided with the reproductive phase. Reduced seed set per cent was observed under $52^{\text {nd }}$ standard week $(72.93 \%)$. However, temperature fluctuations $\left(>29.30 / 13.60{ }^{\circ} \mathrm{C}\right)$ favoured higher pollen fertility under delayed condition $\left(\mathrm{S}_{6}\right)$. The experiment suggested that, critical temperatures during the pre and post anthesis period of sorghum has a greater impact on seed set per cent and pollen fertility that contributes to the total grain yield in sorghum.
\end{abstract}

Keywords: Germination, rabi sorghum, Vigour index, Seed yield

\section{Introduction}

Sorghum is one of the main staple food for the world's poorest and most food insecured people across the semiarid tropics. Globally sorghum is cultivated in 41 mha with a production and productivity of $64.20 \mathrm{mt}$ and $1.60 \mathrm{t} \mathrm{ha}^{-1}$, respectively. With exceptions in some regions, it is mainly produced and consumed by poor farmers. In India, sorghum is cultivated in an area about 5.65 mha with a total annual production of $4.41 \mathrm{mt}$ and productivity of $780 \mathrm{~kg} \mathrm{ha}^{-1}$, while in Karnataka sorghum is grown in an area of 1.09 mha with the total productivity of $1.15 \mathrm{mt}$ and productivity of 1,052 $\mathrm{kg} \mathrm{ha}^{-1}$ (Agricultural statistics, 2016). In India, sorghum crop is being grown in two seasons viz; kharif (rainy) season as a rainfed crop while in rabi (post-rainy) season under residual soil moisture conditions. In general, the productivity levels are higher in kharif season as compared to rabi season. However, In Karnataka average area under rabi sorghum is $85 \%$, average production is $81 \%$. Lack of appropriate hybrids with acceptable grain quality adapted to different agro-ecological situations of rabi season characterized by terminal drought, low temperatures and biotic stresses like shoot fly infestation are the major constraints for higher productivity (Gite et al., 2006). Therefore, there is a need for the development of varieties adapted to specific soil situation in rabi season to enhance production and productivity levels (Jirali et al., 2007). Weather is one key important factor influencing the morphological and phenological traits of sorghum (Safari et al., 2015). Under optimal conditions, sorghum has a high yields potential comparable to other cereals such as rice, maize or wheat (Mohamed, 2011). Variability among genotypes for seed setting behaviour and interaction of lower minimum temperature is observed in sorghum (Reddy et al., 2015). Hence, the study on seed setting behaviour across different temperature regimes helps in choosing a good, potential varieties or hybrid for cultivation. The cultivars like M 35-1, BJV-44 and parental lines of CSH 15-R (MS 104-B and RS-585) are sown in 6 dates with an interval of 10 days from $10^{\text {th }}$ September to $30^{\text {th }}$ October to know the effect of temperature regimes on seed yield and quality traits in rabi sorghum, the present study was undertaken.

\section{Materials and Methods}

The present field experiment was conducted during rabi 
2016-17 at Main Agricultural Research Station (MARS), UAS Dharwad, which is situated at 15012' N latitude and 76034'E longitude with an altitude of 678 above $\mathrm{msl}$. The experimental site consisted of medium deep black soil. The sowing dates were represented in Standard Meteorological Week (SMW). The six dates of sowing was undertaken to create a different temperature regimes $\left(\mathrm{S}_{1}\right.$-Sowing on $10^{\text {th }}$ of September $\left(37^{\text {th }}\right.$ SMW), $\mathrm{S}_{2}$-Sowing on $20^{\text {th }}$ of September ( $\left.38^{\text {th }} \mathrm{SMW}\right), \mathrm{S}_{3}$ Sowing on $30^{\text {th }}$ of September $\left(39^{\text {th }} \mathrm{SMW}\right), \mathrm{S}_{4}$ - Sowing on $10^{\text {th }}$ of October $\left(41^{\text {st }} \mathrm{SMW}\right), \mathrm{S}_{5}$-Sowing on $20^{\text {th }}$ of October $\left(42^{\text {nd }}\right.$ SMW), $\mathrm{S}_{6}$-Sowing on $30^{\text {th }}$ of October $\left(44^{\text {th }} \mathrm{SMW}\right)$. The crop was raised with a spacing of $45 \times 15 \mathrm{~cm}^{2}$, fertilized with 50:20:0 $\mathrm{N}: \mathrm{P}_{2} \mathrm{O}_{5}: \mathrm{K}_{2} \mathrm{O}$. The $\mathrm{T}_{\max }$ and $\mathrm{T}_{\text {min }}$ along with rainfall and humidity was recorded from the meteorological station UAS, Dharwad (Figure 1). The observation on seed yield, quality parameters such as, seedling shoot and root length, seedling dry weight and seedling vigor index were recorded on the $10^{\text {th }}$ day of standard germination test.

\section{Results and Discussion}

\subsection{Quality parameters}

Good quality seed is a pre requisite for higher productivity of crop and it plays an important role in seed production of crop plants. Losses in seed viability and vigour do occur depending upon various factors viz., genetic makeup of the seed material, harvesting stage of seed, environmental conditions at harvesting time and seed size. The mean estimates of the standard germination $(92.60 \%)$, root length $(15.22 \mathrm{~cm})$, seedling vigour index $(3,372)$ and seedling dry weight $(15.94$ $\mathrm{mg}$ ) were observed superior under the September $30^{\text {th }}$ sowing having bold seeds with higher test weight than the seed obtained from other sowings (Table 1 ). The superior performance of the crop sown on September $30^{\text {th }}$ than later sowings in respect of seed quality attributes may be due to favourable environmental condition particularly temperature to which the crop was subjected during vegetative growth,

\begin{tabular}{|c|c|c|c|c|c|c|}
\hline Treatment & $\begin{array}{c}\text { Seed } \\
\text { germination (\%) }\end{array}$ & $\begin{array}{l}\text { Shoot length } \\
(\mathrm{cm})\end{array}$ & $\begin{array}{l}\text { Root length } \\
(\mathrm{cm})\end{array}$ & $\begin{array}{c}\text { Seedling } \\
\text { vigour index }\end{array}$ & $\begin{array}{l}\text { Seedling dry weight } \\
\left(\mathrm{mg} 10 \text { seedlings }^{-1}\right)\end{array}$ & $\begin{array}{c}\text { Seed yield } \\
\left(\mathrm{kg} \mathrm{ha}^{-1}\right)\end{array}$ \\
\hline \multicolumn{7}{|c|}{ Dates of sowing (D) } \\
\hline $37^{\text {th }} \mathrm{SMW}\left(\mathrm{D}_{1}\right)$ & 91.77 & 21.90 & 14.3 & 3324 & 15.3 & 1115 \\
\hline $38^{\text {th }} \mathrm{SMW}\left(\mathrm{D}_{2}\right)$ & 91.46 & 21.97 & 14.54 & 3341 & 15.36 & 1160 \\
\hline $39^{\text {th }} \mathrm{SMW}\left(\mathrm{D}_{3}\right)$ & 92.60 & 21.19 & 15.22 & 3372 & 15.94 & 1378 \\
\hline $41^{\text {st }} \mathrm{SMW}\left(\mathrm{D}_{4}\right)$ & 91.93 & 20.35 & 14.83 & 3234 & 15.85 & 1212 \\
\hline $42^{\text {nd }} \operatorname{SMW}\left(D_{5}\right)$ & 90.72 & 20.59 & 14.49 & 3183 & 15.23 & 1063 \\
\hline $44^{\text {th }} \mathrm{SMW}\left(\mathrm{D}_{6}\right)$ & 87.08 & 21.15 & 14.13 & 3072 & 15.09 & 860 \\
\hline SEm \pm & 2.03 & 0.21 & 0.18 & 30.82 & 0.18 & 50.29 \\
\hline$C D(p=0.05)$ & 0.53 & 0.67 & 0.58 & 97.12 & 0.55 & 158.4 \\
\hline \multicolumn{7}{|l|}{ Varieties (V) } \\
\hline M 35-1 $\left(V_{1}\right)$ & 92.29 & 20.45 & 14.13 & 3202 & 15.35 & 1169 \\
\hline MS 104-B $\left(V_{2}\right)$ & 90.55 & 22.06 & 14.63 & 3314 & 15.33 & 996 \\
\hline RS-585 $\left(V_{3}\right)$ & 87.70 & 20.24 & 14.84 & 3076 & 15.49 & 1043 \\
\hline BJV-44 $\left(V_{4}\right)$ & 93.17 & 22.02 & 14.74 & 3426 & 15.67 & 1317 \\
\hline SEm \pm & 0.53 & 0.39 & 0.11 & 40.05 & 0.09 & 30.16 \\
\hline $\mathrm{CD}(p=0.05)$ & 1.53 & 1.12 & 0.32 & 114.9 & 0.25 & 86.5 \\
\hline \multicolumn{7}{|l|}{ Interactions } \\
\hline$D_{1} V_{1}$ & 92.53 & 22.07 & 13.89 & 3328 & 15.33 & 1060 \\
\hline$D_{1} V_{2}$ & 91.53 & 22.05 & 14.61 & 3356 & 15.19 & 1029 \\
\hline$D_{1} V_{3}$ & 88.13 & 20.24 & 14.47 & 3059 & 15.36 & 1043 \\
\hline$D_{1} V_{4}$ & 94.86 & 23.23 & 14.24 & 3553 & 15.34 & 1329 \\
\hline$D_{2} V_{1}$ & 93.26 & 21.61 & 14.52 & 3369 & 15.21 & 1187 \\
\hline$D_{2} V_{2}$ & 91.00 & 22.88 & 14.33 & 3387 & 15.03 & 1026 \\
\hline$D_{2} V_{3}$ & 87.33 & 21.01 & 14.69 & 3118 & 15.24 & 1119 \\
\hline $\mathrm{D}_{2} \mathrm{~V}_{4}$ & 94.26 & 22.40 & 14.63 & 3490 & 15.95 & 1306 \\
\hline
\end{tabular}




\begin{tabular}{lcccccc}
\hline Treatment & $\begin{array}{c}\text { Seed } \\
\text { germination }(\%)\end{array}$ & $\begin{array}{c}\text { Shoot length } \\
(\mathrm{cm})\end{array}$ & $\begin{array}{c}\text { Root length } \\
(\mathrm{cm})\end{array}$ & $\begin{array}{c}\text { Seedling } \\
\text { vigour index }\end{array}$ & $\begin{array}{c}\text { Seedling dry weight } \\
\left(\mathrm{mg} \mathrm{10} \mathrm{seedlings}^{-1}\right)\end{array}$ & $\begin{array}{c}\text { Seed yield } \\
\left(\mathrm{kg} \mathrm{ha}^{-1}\right)\end{array}$ \\
\hline $\mathrm{D}_{3} \mathrm{~V}_{1}$ & 92.72 & 19.95 & 14.37 & 3182 & 15.95 & 1358 \\
$\mathrm{D}_{3} \mathrm{~V}_{2}$ & 92.01 & 22.40 & 15.34 & 3473 & 15.66 & 1355 \\
$\mathrm{D}_{3} \mathrm{~V}_{3}$ & 90.73 & 20.69 & 15.65 & 3298 & 15.9 & 1292 \\
$\mathrm{D}_{3} \mathrm{~V}_{4}$ & 94.94 & 21.71 & 15.52 & 3535 & 16.23 & 1508 \\
$\mathrm{D}_{4} \mathrm{~V}_{1}$ & 92.33 & 19.47 & 14.57 & 3145 & 15.54 & 1163 \\
$\mathrm{D}_{4} \mathrm{~V}_{2}$ & 91.40 & 21.71 & 14.86 & 3341 & 15.92 & 1076 \\
$\mathrm{D}_{4} \mathrm{~V}_{3}$ & 89.33 & 19.21 & 14.99 & 3051 & 16.11 & 1293 \\
$\mathrm{D}_{4} \mathrm{~V}_{4}$ & 94.65 & 21.00 & 14.90 & 3399 & 15.82 & 1317 \\
$\mathrm{D}_{5} \mathrm{~V}_{1}$ & 92.20 & 20.58 & 13.84 & 3174 & 15.15 & 1206 \\
$\mathrm{D}_{5} \mathrm{~V}_{2}$ & 92.00 & 22.68 & 14.39 & 3411 & 15.02 & 861 \\
$\mathrm{D}_{5} \mathrm{~V}_{3}$ & 88.33 & 18.42 & 15.41 & 2987 & 15.35 & 855 \\
$\mathrm{D}_{5} \mathrm{~V}_{4}$ & 90.33 & 20.68 & 14.31 & 3162 & 15.40 & 1327 \\
$\mathrm{D}_{6} \mathrm{~V}_{1}$ & 90.67 & 18.99 & 13.56 & 3017 & 14.93 & 1041 \\
$\mathrm{D}_{6} \mathrm{~V}_{2}$ & 85.33 & 20.61 & 14.26 & 2916 & 15.16 & 630 \\
$\mathrm{D}_{6} \mathrm{~V}_{3}$ & 82.33 & 21.87 & 13.85 & 2940 & 14.99 & 652 \\
$\mathrm{D}_{6} \mathrm{~V}_{4}$ & 89.99 & 23.13 & 14.86 & 3417 & 15.27 & 1117 \\
$\mathrm{SEm} \pm$ & 1.31 & 0.95 & 0.27 & 98.1 & 0.21 & 73.87 \\
$\mathrm{CD}(p=0.05)$ & $\mathrm{NS}$ & $\mathrm{NS}$ & $\mathrm{NS}$ & $\mathrm{NS}$ & $\mathrm{NS}$ & 211.9 \\
\hline & & & & & & \\
\hline
\end{tabular}

flowering, seed setting and seed maturity. Similar findings were reported by Palanisamy and Ramasamy (2001) who noticed significant and positive correlation of temperature with number of flower, fruits plant ${ }^{-1}$, seed germination and seedling vigour. Among the varieties the mean values for higher seed germination (93.17\%) and seedling vigour index $(3,426)$ and seedling dry weight $(15.67 \mathrm{mg})$ was observed in BJV-44, however higher root length was recorded in RS$585(14.84 \mathrm{~cm})$ and was on par with BJV-44 $(14.74 \mathrm{~cm})$ and highest shoot length was found in MS 104-B $(22.06 \mathrm{~cm})$ which was also found on par with BJV-44 $(22.02 \mathrm{~cm})$. The variation between the varieties might be due to variation in expression of characters fully in the favourable environmental conditions reported by Mohankumar et al. (2013); Rayhan et al. (2016).

Among the interactions, higher germination (94.94\%) and seedling dry weight $\left(16.23 \mathrm{mg}\right.$ ) was found under $\mathrm{S}_{3} \mathrm{~V}_{4}$ combination. The higher yield and seed quality parameters might be due to optimum temperature in early sown crop which was beneficial for the early establishment of crop and subsequent proper growth, resulting in producing more height, foliage and higher number of seeds panicle ${ }^{-1}$ and seed weight which ultimately resulted in higher yield and seed quality and full expression of the varietal characters during favourable conditions, which existed during early sown crops. These results are also in conformity with Samarah et al. 2006 in barley, reported that yield and yield components were improved by early planting date as compared with late planting date.
Thus, the present study confirmed that, the crop environment that gives higher seed yield also produces seed lot with high germination and vigour index. Variation in seed germination and vigour due to variation in sowing date has also been reported by earlier workers (Rahman et al., 2005; Rahman et al., 2013). The variation in seed germination and vigour comes from the environmental conditions that the crop experiences during the seed development and maturation. Seed germination and vigor rapidly decreased in seeds exposed to adverse environmental conditions, when parental plants are exposed to high temperature during growth and development the quality of seed is highly influenced in wheat (Hasan et al., 2013); Hampton et al. (2005) also reported that higher individual seed weight might have been related to higher germination of the crop. The seed lot showing higher seedling vigour index is considered to be more vigorous and a decreased vigour index was observed with delayed sowing in rabi soybean (Rahman et al., 2013). The results are also in agreement with the findings of Ayyub et al. (2007) who reported that physiologically matured seeds exhibited better viability and seed quality.

\subsection{Yield and reproductive efficiency}

Among the genotypes BJV-44 recorded significantly higher seed yield $\left(1,317 \mathrm{~kg} \mathrm{ha}^{-1}\right)$ compared to rest of the genotypes. Among the date of sowing September $30^{\text {th }}$ sowing recorded significantly higher seed yield $\left(1,378 \mathrm{~kg} \mathrm{ha}^{-1}\right)$ compared to rest of the treatments. Whereas, late sowing during $30^{\text {th }}$ 
October recorded significantly lower seed yield (840.6 kg ha $\left.{ }^{1}\right)$. This is probably due to early sown crop enjoy favourable climatic conditions in terms of temperature and other climatic parameters during various crop growth stages, which reflected in better growth. The significant grain production is ascribed to favourable temperatures at different growth stages, which may increase photosynthetic rate, assimilates the supply for seed growth rate with early sown crops than in late sown crop (Aslani and Mehrvar, 2012). The improvement in grain yield to an extent of 997.2 to $1,317 \mathrm{~kg} \mathrm{ha}^{-1}$ was due to greater genetic ability of variety to translocate the photosynthates to economic part. Crop yield depends not only on the accumulation of photosynthates during the crop growth and development, but also on it's translocation in the desired storage organs. These inturn, are influenced by the efficiency of metabolic processes within the plant (Verma et al., 2012). Interaction effects revealed that genotype BJV-44 planted during $30^{\text {th }}$ of September recorded significantly higher seed yield $\left(1,508 \mathrm{~kg} \mathrm{ha}^{-1}\right)$ as compared to rest of the interactions. Under $48^{\text {th }} \mathrm{SMW}$ maximum temperature $\left(31.40^{\circ} \mathrm{C}\right)$ coincided with the reproductive phase in genotype BJV-44 (Table 2). This resulted in increased pollen fertility (89.10). However, this temperature favoured higher seed set per cent (81.13\%) compared to other dates of sowing. Further, under delayed sowing $\left(52^{\text {nd }} \mathrm{SMW}\right)$ lower temperature (Figure 1 ) was recorded

Table 2: Seed set per cent and pollen fertility per cent of genotype BJV-44 under six sowing dates

\begin{tabular}{cccccc}
\hline Variety & $\begin{array}{c}\text { Flowering } \\
\text { week (SMW) }\end{array}$ & $\begin{array}{c}\text { Max. } \\
\text { Temp } \\
\left({ }^{\circ} \mathrm{C}\right)\end{array}$ & $\begin{array}{c}\text { Min. } \\
\text { Temp } \\
\left({ }^{\circ} \mathrm{C}\right)\end{array}$ & $\begin{array}{c}\text { Seed } \\
\text { set per } \\
\text { cent }\end{array}$ & $\begin{array}{c}\text { Pollen } \\
\text { fertility } \\
\text { per cent }\end{array}$ \\
\hline BJV-44 & $46^{\text {th }}$ SMW & 31.00 & 17.50 & 79.13 & 79.72 \\
& $47^{\text {th }}$ SMW & 30.10 & 13.10 & 78.13 & 78.68 \\
& $48^{\text {th }}$ SMW & 31.40 & 13.10 & 81.13 & 89.10 \\
& $49^{\text {th }}$ SMW & 29.60 & 15.60 & 78.73 & 88.29 \\
& $52^{\text {nd }}$ SMW & 30.50 & 11.80 & 72.93 & 73.10 \\
& $2^{\text {nd }}$ SMW & 29.60 & 13.60 & 78.33 & 90.18 \\
\hline
\end{tabular}

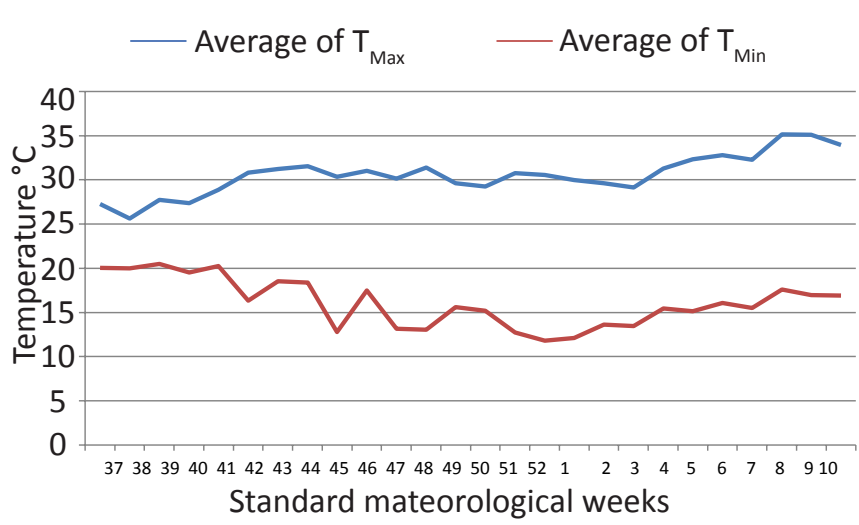

Figure 1: Weekly meteorological data of Minimum and maximum temperature (OC) for the crop growing period 2016-17 $\left(11.80{ }^{\circ} \mathrm{C}\right)$ which influenced on the seed sitting per cent (72.93\%). This indicated that, seed setting per cent depends on the range of maximum and minimum temperature over the reproductive phase of flowering. Under delayed sowing reduced pollen fertility was recorded $(73.10 \%)$. This results indicated that critical temperatures during the pre and post anthesis period of sorghum has a greater impact on seed set per cent and pollen fertility that contributes to the total grain yield in sorghum.

\section{Conclusion}

Among all the sowing dates and genotypes, sowing during September $30^{\text {th }}\left(\mathrm{S}_{3}\right)$ was optimum and the genotype BJV-44 $\left(V_{4}\right)$ was found good for getting higher yield and quality in rabi sorghum under northern transition zone.

\section{References}

Agricultural Statistics at a Glance 2016. Department of Agricultural Cooperation and Farmers Welfare, Ministry of Agriculture, Government of India, http:// eands. dacnet.nic.in., 97-99.

Aslani, F., Mehrvar, M.R., 2012. Responses of wheat genotypes as affected by different sowing dates. Asian Journal of Agricultural Science 4(1), 72-74.

Ayyub, C.M., Ziaf, K., Pervez, M.A., Rasheed, M.A.S., Akhtar, N., 2007. Effect of seed maturity and storability on viability and vigour in pea (Pisum sativum L.) seeds. In: Proceedings of International Symposium prospects of Horticultural Industry, University of Agriculture., Faisalabad, 28-30th March, 269-273.

Gite, B.D., Kahate, P.A., Ratnaparkhi, R.D., Ghodpage, R.M., Anokar, D.N., 2006. Identification of some new rabi sorghum hybrids for shoot fly resistance and grain yield. Annals of Plant Physiology 20(1), 154-155.

Hampton, J.G., Rahman, M.M., Mwakangwale, M.G., Hill, M.J., 2005. Does seed weight explain seed vigour differences in seeds from different pod positions on the plant. Seed Science and Technology 33, 499-503.

Hasan, M.A., Ahmad, J.U, Hossain, T., Mian, M.A.K., Haque, M. M.,2013. Evaluation of the physiological quality of wheat seed as influenced by high parent plant growth temperature. Journal of Crop Science and Biotechnology, 16, 69-74.

Jirali, D.I., Biradar, B.D., Rao, S.S., 2007. Performance of rabi sorghum genotypes under receding moisture conditions in different soil types. Karnataka Journal of Agricultural Sciences, 20, 603-604.

Mohamed, S.S., 2011. Genetic diversity among some sudanese sorghum accessions using molecular markers and phenoty pic characterization. Thesis of Msc-Sudan Academy of Sciences.

Mohankumar, B.N., Basavegowda, Vyakaranahal, B.S., Deshpande, V.K., Kenchanagoudar, P.V., 2013. Influence of sowing dates on production of seed yield in niger 
(Guizotia abyssinica Cass.). Karnataka Journal of Agricultural Sciences 24(3), 289-293.

Palanisamy, V., Ramasamy, K.R., 2001. Influence of environmental factors on production and quality of seeds in bhendi [Abelmoschus esculentus (L.) Moench]. South Indian Journal of Horticulture 33(I), 58-59.

Rahman, M.M., Hampton, J.G., Hill, M.J., 2005. Soybean seed yield as affected by time of sowing in a cool temperature environment. Seed Science and Technology 7, 1-15.

Rahman, M.M., Hossain, M.M., 2013. Effect of sowing date on germination and vigour of Soybean (Glycine max (L.) Merril) seeds. The Agriculturists 11(1), 67-75.

Rayhan, S., Nazmul, I., Siddikur, R., Ashratun, N., 2016. Effect of sowing time and variety on seed germination and vigour index of wheat. Bangladesh Journal of Agricultural Research 41(1), 127-136.
Reddy, P.S., Patil, J.V., Krishna, T.P., 2015. Response of diverse groups of sorghum genotypes to low temperature stress at anthesis. Indian Journal of Genetics and Plant Breeding 74(4), 444-449.

Safari, M., Aghalikhani, M., Sanvey, S.A.M.M., 2010. Effect of sowing dates on planting and morphological traits of three grain sorghum cultivars. Indian Journal of Crop science. 12, 452-466.

Samarah, N.H., Taha A.A., 2006. Effect of planting date on seed yield and quality of barley grown under semi-arid Mediterranean conditions. Journal of Food, Agriculture and Environment 4(2), 222-225.

Verma, R.P.S., Kumar, V., Kharub, A.S., Kumar, D., Selvakumar, R., 2012. Journal of Wheat Research 5(1), 59-62. 